\title{
The Humanities and Social Sciences Laboratory as a Motivating and Innovative Strategy in High School Education ${ }^{+}$
}

\author{
Mario Corrales Serrano 1,** José Moreno Losada ${ }^{1}$, Jesús Sánchez Martín ${ }^{2}$ and \\ Francisco Zamora Polo ${ }^{3}$ \\ 1 Departamento de Didáctica de las Ciencias Sociales, las Lenguas y las Literaturas. Facultad de Educación, \\ Universidad de Extremadura, 06071 Badajoz, Spain; jmorenol@unex.es \\ 2 Departamento de Didáctica de las Ciencias Experimentales y las Matemáticas, Facultad de Educación, \\ Universidad de Extremadura, 06071 Badajoz, Spain; jsanmar@unex.es \\ 3 Departamento de Ingeniería Mecánica, Energética y de los Materiales. Escuela de Ingenierías Industriales, \\ Universidad de Extremadura, 06071 Badajoz, Spain; fzamora@unex.es \\ * Correspondence: mariocorralesserrano@gmail.com; Tel.: +34-674964987 \\ + Presented at the 2nd Innovative and Creative Education and Teaching International Conference \\ (ICETIC2018), Badajoz, Spain, 20-22 June 2018.
}

Published: 26 October 2018

\begin{abstract}
The present work is the result of a research carried out in the stage of High School education, in the area of Humanities and Social Sciences. The data show that, at this stage, in which High School students begin to decide on a study modality that allows them access to the university, there is a majority of students who decide on the Science modality, to the detriment of the others. As a response to this situation, we have designed a tool that allows teachers in this area and this stage to transmit, in a more effective way, the practical and useful dimension of social and humanistic knowledge: The Humanities and Social Sciences laboratory. This experience, which is better known in the university field, is hardly used in secondary education. We offer the design of what could be a practical-didactic experience for this area and for its curricular contents.
\end{abstract}

Keywords: didactic; social sciences; utility

\section{Introduction}

The analysis of enrollment data in the Assessment of High School Students for Access to the University (EBAU-acronym in Spanish) allows us to observe an imbalance between the number of students who decide on the Experimental Sciences modality, which brings together more of the half of the students enrolled, and the rest of the modalities (Humanities, Social Sciences and Arts), in which the other half is enrolled. Some motivation studies carried out by the Teaching Innovation Group "Ethics of University Teaching Staff" of the UEX, allow us to point out, as possible causes of this imbalance in the preferences of high school students, the lack of practical application and of a useful vision of these academic disciplines.

In this paper we present a detailed analysis of this situation of imbalance following three steps:

- Presentation of the data referring to the preference of the study modalities of High School students, especially those who are in the final stage, closest to the completion of the EBAU.

- Analysis of motivational factors that explain this situation.

- Design of the Humanities and Social Sciences laboratory for the High School education stage, as a response to those motivational imbalance factors of students in relation to such subjects. 


\section{Experimental Phase}

In this work we have carried out a study of hybrid methodology, applying a questionnaire of quantitative type and the qualitative analysis of texts that is developed by the students, in order to determine the internal and external motivations that are behind the choice of modality in the Secondary Education and in the EBAU. When crossing the results of both procedures some interesting conclusions appears, which are very useful as a starting point for the educational practice we have designed:

- In the last stage of the High School, there are more students who opt for the Science modality than for the other available modalities (Humanities, Social Sciences and Arts).

- Among the causes that motivate this choice, there is a balanced assessment of the causes with an internal motivation (they all value them in the same way); however, in terms of external motivation factors (the possibility of finding a job, utility, socioeconomic level), students who decide on the modality of Science value these criteria with higher scores than those of the other modalities.

- The causes of external motivation, among which more differences can be seen, can be summarized in two major ideas: the utility and the practical application of knowledge [1].

\section{Didactic Proposal}

As a conclusion and response to the motivational analysis carried out by us on the modality options of the study, we present the design of an innovative didactic strategy for the classroom of Humanities and Social Sciences in the secondary education: The practical laboratory of Humanities and Social Sciences. This didactic strategy, currently present in the University faculties, but with very little extension at the level of secondary education, has two main objectives:

- Move from a theoretical education to a practical teaching of these subjects.

- Try to show the usefulness of humanistic and social knowledge in all its dimensions.

The methodology and the didactic proposal focused on problem-based learning (PBL) and also on active and practical methodologies, following the usual steps of this methodology.

From our point of view, the proper scope of application of this tool is the Department of Humanities and Social Sciences of the High School center. In order to make this decision, we take into account some relevant factors:

- Firstly, we rely on those factors related to previous experience: the experiences that we already know the department have as its own scope of application [2,3].

- Secondly, we take into account the competences assigned to the pedagogical departments. These are analyzed as they appear in current regulations. We note that some of them correspond to the type of tool we are proposing. Let's see some of these competences [4] (p. 46):

(a) Formulate proposals to the Board of Directors and the Diocesan authorities (Faculty). Regarding the elaboration of the educational project of the institute and the annual general programming.

(b) Formulate proposals to the Pedagogical Coordination Committee related to the elaboration of the curricular projects for the stage.

(c) Prepare, before the start of the academic year, the didactic programming of the corresponding teachings for each of the areas, subjects and modules integrated in the department, under the coordination and direction of the Head of this, and in accordance with the general guidelines established by the pedagogical coordination commission. In the didactic programming will be included, for each stage, the aspects indicated in Article 99 of this Regulation. 
(d) Promote educational research and propose activities for the improvement of its members.

(e) Maintain the didactic methodology duly updated.

(f) Collaborate with the Guidance Department in the prevention and early detection of learning problems, as well as in the programming and application of curriculum adaptations for students who need it.

(g) Organize and carry out complementary activities in collaboration with the corresponding department.

Propose optional subjects that are dependent on the Department, which will be taught by the professors of the same [4] (p. 48).

- In third and last place, the pedagogical department seems to us to be the most appropriate environment, given the purpose of the tool we are designing. The intrinsic and extrinsic motivational analysis that we have done, indicates that the lack of extrinsic motivation refers to all the subjects of the Humanities modality in general, and not to one of them in particular. If the objective is to reverse this situation, little could be achieved if actions are presented separately from a single subject, group or course. It would seem more successful to act globally, from all the subjects that make up the didactic scope of the Humanities modality [5].

All these reasons lead us to think that the ideal field for the development of a Humanities laboratory is, as we have said before, the Department of Humanities and Social Sciences. Once this decision has been made, it would be necessary to specify how to carry out this implementation. Leaving open the door to the creativity of the department itself, we believe that the department's programming should include, at least, one objective and a few resources that would make possible the implementation.

Objective: To develop the practical application of the competences studied in the subjects belonging to the department, with the purpose that the student can perceive the practical application and the usefulness of what he studies.

\section{Resources:}

- A space equipped with the instruments and tools that are necessary for the practical development of each of the subjects.

- Interdisciplinary work.

- Theoretical-practical methodologies.

- That each subject has at least one practical proposal at each level and for each course, with the department being responsible for distributing them over time.

Key competences: The practical application that is intended to achieve with the design of these practical activities, linked to the idea of the laboratory, should be associated with the acquisition of key competences by the students.

Evaluation: Each one of the practices will be evaluated with a rubric designed within the project of the same practice. Likewise, a percentage of the final grade will be assigned.

\section{References}

1. Corrales, M.; Sánchez, J.; Moreno, J. The motivation in the teaching of social sciences at the High School: NOVA. J. Educ. Res. 2016, 10, 182.

2. Santacana, J. Reflexiones en torno al laboratorio escolar en ciencias sociales. Íber. [Versión Electrónica] 2005, 43, 7-14.

3. Quinquer, D. Estrategias metodológicas para enseñar y aprender ciencias sociales: Interacción, cooperación y participación. Íber 2004, 40, 18. 
4. Prats, J. Líneas de investigación en didáctica de las ciencias sociales. In História E Ensino Revista do Laboratório de Ensino de Históriória/UEL; Universidade Estadual de Londrina: Londrina, Brazil, 2003; Volume 9, p. 46.

5. García Andrés, J. Mecanismos motivadores en la enseñanza de la Historia. Un modelo de aplicación con alumnos de ESO. Clío 2011, 37. Available online: http://clio.rediris.es/n37/articulos/garcia2011.pdf (accessed on 25 October 2018).

(C) 2018 by the authors. Licensee MDPI, Basel, Switzerland. This article is an open access article distributed under the terms and conditions of the Creative Commons Attribution (CC BY) license (http://creativecommons.org/licenses/by/4.0/). 